\title{
The Strategies of Staging the Choices of Degrees of Formalization of Business Activities in Cameroon
}

\author{
Abaté André Modeste ${ }^{1}$, Fouda Ongodo Maurice ${ }^{1}$, Pene Zongabiro Nina Pelagie ${ }^{2}$ \\ ${ }^{1}$ Faculty of Economics and Management, University of Douala, Douala, Cameroon \\ ${ }^{2}$ Ministry of Sport and Physical Education, Yaounde, Cameroon \\ Correspondence: Pene Zongabiro Nina Pelagie, Ministry of Sport and Physical Education, Po. Box 1016 Yaounde, \\ Cameroon.
}

Received: September 7, 2017

doi:10.11114/aef.v4i6.2725
Accepted: October 19, $2017 \quad$ Available online: October 23, 2017

URL: https://doi.org/10.11114/aef.v4i6.2725

\begin{abstract}
The objective of this work is to highlight the strategies of formalization and the development of activities base on the analysis of the path of the formalization of the activities of six entrepreneurs in Cameroon. The study used live recitation of entrepreneurs obtained through a semi-direct interview that focuses on three main questions including: the circumstances of the engagement in an entrepreneurship carrier, the legal status of the activities and the evolution of the activities. The results revealed that despite the accumulation capacity of entrepreneurs, they continue to act in an informal manner by convenience and opportunism. This study, therefore dissociates with the established idea that small business entrepreneurs do not have strategic abilities. In fact, the results show that entrepreneurs in the informal sector have strategic abilities that enable them to put in place and at some level strategies of formalization that can guarantee good performance and reduce constraints towards the development of their activities.
\end{abstract}

Keywords: strategies, formalization, development path, transitional dynamics, facade

\section{Introduction}

Economic development and informal entrepreneurship are linked. According to LaPorta and Schleifer (2014), as countries being developed, the informal economy tends to diminish and favour the domination of formal one. Meanwhile, the Cameroon government through its planning document, named Strategic Document for Growth and Employment focus on the entrepreneurs of the informal sector as major actors in the development process and entrepreneurship promotion of the country. To reduce the importance of the informal sector, the government has put in place two main measures: the firsts one aims to encourage the migration of investment from informal sector to formal one. These measures are inciting (commercial, financial; fiscal and administrative) and persuading (sensitization campaigns, support structures and counselling); the second measures aim to discourage the entrance in the informal sector. These measures are dissuasive (reinforcement of the controls and the applications of sanctions). However, the decisions of the actors of the informal sector to improve their legal and administrative situation (be registered in the state documents and be conformed to legal rules and procedures) depends on the evaluation they make in term of cost and advantages.

The results obtained in some studies show that several enterprises started in the informal sector with the aim of testing the sustainability of their activities before becoming formal (Williams \& Martinez, 2014). On the contrary, Hugon (2014) argued that when their profits do enable them, small entrepreneurs prefer to diversify their activities instead of transforming the small unit into a medium sized enterprise with paid workers, accounting and taxation. While Menguelti, Perret and Abrika (2014), instead indicate that some entrepreneurs develop firms that are formally declared but with informal practices (use of bills, declaration of employees, bank registration).

The above authors' views highlight the existence of a transitional dynamic of enterprises and the choice of some entrepreneurs to refuse the formalization of activities mainly when the activities are at the stage of accumulation. However, if some researchers are interested in the question on why entrepreneurs formalize their activities, fewer researchers are dealing with the question on how entrepreneurs make the choice. Meanwhile, this paper aims at answering two main questions: do entrepreneurs of informal sector can have strategic abilities to choose structural and juridical form for the development of their activities? In addition, how do they put in place these choices? 
In order to study transitional dynamics of informal enterprises, the study focuses on the evolution of six entrepreneurs from informal sector with respect to two processes of relationship with the State including: legal process and taxation process. Another aspect of the study is to understand the strategy of the presentation of the level of formalization of activities developed by entrepreneurs. The study also used the metaphor of 'facade' developed by Goffman (1973) to describe the strategic of self-representation. The results obtained from respondents revealed that they distinguish themselves through: the logic of the presentation of the level of formalization that they put in place, formal (with respect to the creation or legalization process), and informal activities (with respect to functioning process mainly the taxation process), and wholly or partly informal activities. Finally, enterprises are not wholly formal neither wholly informal, however they appear to be formal or informal.

This paper is organized as follows: the next sections present, literature review (2) methodology (3); results and discussion (4), and conclusion (5).

\section{Literature Review}

\subsection{The Choice of Conformity as a Dynamic Path}

When is come to study informal economy, researchers usually opposed static and dynamic perspectives. The static point of view is generally descriptive and focuses on the size of the enterprise, the nature of industrial relationship, the degree of consideration of fiscal and social legislation, and the level of conformity to accounting practices. The dynamic perspective refers to the study of mobility or the dynamism of the enterprises from one sector to another. In this study, the development path of enterprises is considered as a dynamic choice regarding the degree of formalization of activities (legal or fiscal) and the choice of the strategies of the development of activities (linear growth versus extensive growth through the multiplication of activities).

The static perspective stresses the relationship between State and entrepreneurs that include two processes: legal formality and taxation or economic formality.

According to Mouko (2015), juridical formality describes the degree of registration of businesses with the public authorities and the free enjoyment of property rights. The path of formalization consists in the transformation of de facto enterprises into legal enterprises. A transformation that is in the form of a continuum state is a process that reveals mainly legal characteristic. Thus, from a state of legal inexistence, the enterprise moves to a state of real legal existence and this process is juridical formality. However, the evolution of the relationship between the entrepreneur and the State can also be marked by a process of informality that consists of transforming legal enterprises into de facto enterprises. Another transformation is the evolution of activities that can move from the launching stage to the developed one. However, some entrepreneurs can choose to maintain the activities either in the informal sector or in the formal sector.

According to juridical formality, transitional dynamics of firms can have three paths: positive (formalization), negative (informality), and a status quo.

Moreover, the transformation path of status is not uniform. According to Mouko (2015), the analysis of the process reveals the existence of two modalities of transformation of enterprises: (i) a progressive or gradual movement and (ii) a direct path to legal formalization. In the first case, the enterprises move directly from the initial 'facto' state, passes through several hybrid legal states (or semiformal) before ending up with a formal legal state. In the second case, firms move directly from the status of 'de facto' enterprise to a legal enterprise.

However, the change in legal status despite different protections (right to use and enjoy property rights related to legal existence), also brings constraints such as the payment of different tariffs and taxes. Nevertheless, it is very common to see an enterprise being placed either above or below its tax category. This fact is very current when the enterprises minimise their turnover (false declaration of turnover), existence of double accounting ...etc). In fact, this situation appears when the managers of the enterprise want to have the advantages of formality without accepting some charges links to the change.

The gap between legal formalization and economic or fiscal formalization also exists such as revealed in some empirical studies. Indeed, Mead and Morrisson (1996) from sample of seven countries, and Diagne and Thiaw (2008) studied 246 informal production units in Senegal, found out that the degree of applying regulations is variable and the real tax contributions are less frequent and less observed compared to registration.

The second process is the mode of development of activities. This process deals with the mode of accumulation chosen. According to the literature (Labazee, 2000), the accumulation can be extensive or intensive. However, small firms rarely get involved in an intensive accumulation process (reinvesting in established firms) and instead choose extensive accumulation (diversification of productive investments in several small size firms). Berrou (2014), highlights the role of fiscal exit: the intensive accumulation increases the visibility and consequently taxation risk. Extensive accumulation responds to the logic of solidarity or the creation of a new production unit that enables to hire a family member or a member of a network. 


\subsection{Setting up the Choices of the Paths of Formalization of Business Activities}

The analysis of the relationship between a rational entrepreneur and its institutional environment can be done with the help of the notion of self-representation developed by Goffman (1973). In fact, this author suggests that the actor uses whatever he has in order to give an ideal impression of himself to his audience (public). In this game of role, the actor can choose to dissimulate activities that are no longer worthwhile in the eyes of the public and could distort the image that he wishes to project (or the representation). One can therefore think that within the framework of the choice of the development path of its activities, the entrepreneur does everything possible to present a legal conformity of its activities to the public, whereas he discretely tries to dissimulate results (profits) to pay less tax.

According to Goffman (1973), the main component of self-representation is a facade. The author uses the theatre metamorphosis as a framework of his analysis. He highlights that, when an individual climbs on the stage, he tries to project a certain image of himself. The facade is the part of representation that has a normal function, to establish and arrange the definition of the situation that is proposed to observers [...] is a symbolic appearance usually used by the actor.

According to Goffman (1973), facade has two faces. The anterior/pure region is the space of the game in front of the public, where the facade is shown. In this region, the actor applies anticipated rules. And the posterior region/dissimulated and generally forbidden to the public, where the actor prepares himself, removes his masque, produces and arranges his decorations. The behaviour of an actor can be either coherent or distorted between two faces (pure and dissimulated side) and he chose to project one face or another to his public.

The entrepreneur as well as theatre actor can also choose a strategy of coherent facade or of sincerity between pure (honest) and dissimulated side. Two groups of enterprises can therefore be identified: firstly, legalised enterprises (the perfect side) and conform to regulatory obligations (dissimulated side). Secondly, illegalised enterprises (perfect side), because their turnover does not reach the minimum of regulatory amount required (dissimulated side). This will therefore be a strategy of citizen entrepreneurs who observe an ethical behaviour and refuse the arrangements that does not favour the State. In other words, they prefer collective well-being by applying regulations instead of their personal well-being through the manipulation of accounts or 'negotiation' with government officials.

The entrepreneur can also choose a strategy of 'dissonant facade'. In this case, he can choose to legalise (perfect side) and do not submit himself totally or partially to fiscal and social constraints (fraud, dissimulated side), or do not legalise the activities even when the level of turnover generated requires it (perfect side) and diversify the activities so as to avoid conforming to fiscal and social obligations (distorted side). These two cases are similar to the strategies of fraud management (Cheriet, 2013) or the fraud triangle of Wells (1997) with the extremity of the triangle being: opportunity, pressure/incentive, and rationalisation, moral and ethical pre-disposition. Some empirical applications realised by several studies have enabled to test and validate the concept of fraud management (Van Peursem, Zhou, Flood \& Bultimore, 2007). Table1 present different facades of staging degrees of formalization of activities.

Table 1. Different facades of staging different degrees of formalization of business activities

\begin{tabular}{ll}
\hline Coherent facade & Dissonant façade \\
\hline Formal (legalised and operating legally) & $\begin{array}{l}\text { formal appearance (Legalised but running does not conform } \\
\text { to the regulations) }\end{array}$ \\
$\begin{array}{ll}\text { Informal (not legalised and functioning } \\
\text { does not conform to the regulations) }\end{array}$ & $\begin{array}{l}\text { Informal appearance (not legalised but turnover is more than } \\
\text { the minimum required) }\end{array}$ \\
\hline
\end{tabular}

Source: Authors own elaboration

Table 1 revealed that the actors do not always play a game that conforms to the expectations of the institution. They usually deviate from the role or roles expected from them and try to modify the norms, the rules, and the practices.

\section{Methodology of the Study}

This study used qualitative approach. The qualitative studies involve the fact of taking into account the singularity of the subject of study base on a given context. Indeed, the qualitative approach main objective is a deep study of a given phenomenon (Yin, 1994). According to Rispal and Jouison-Laffitte (2015) in entrepreneurship, case studies can be mobilised when the objective of the research consists to construct a theory or to understand a process. These authors added that the research questions often including the words: 'how' 'process', 'development', 'evolution', 'dynamic', 'change', 'construction', etc. The choice of multiple case study was prioritised and six cases were chosen. Number 6 seems satisfactory according to the recommendations of Eisenhardt (1989) and Yin (2003). In fact, Eisenhardt (1989) proposed a minimal of four cases and a maximal of ten cases and Yin (2003) propose two or three cases when the objective is a literal replication, where the study consists of finding similar results in each of the cases with less or important degree of certainty. On the contrary, when the study aims, to looking for more certainty, the number of cases is increased.

The following criteria were used to select respondents: (1) enterprises that have more than three years of existence 
(since the taxation law give two years of exception of license tax for new creations), (2) a minimum of three permanent employees and (3) a turnover that is more than or less than the regulatory limit and belonging to a simplified tax regime (that is 10 million CFA Francs).

Data collection was carried out through a semi-direct interview made up of three major questions including: (1) what are the circumstances of your engagement in an entrepreneurship career? (2) Talk us about the legal status of your activities at the onset? (3) How and why did your activities developed?

Table 2. The Demographic Characteristics of Entrepreneurs

\begin{tabular}{|c|c|c|c|c|c|c|c|c|c|}
\hline Case & Age & Gender & $\begin{array}{l}\text { Education } \\
\text { level of }\end{array}$ & $\begin{array}{l}\text { Previous } \\
\text { experiences }\end{array}$ & $\begin{array}{l}\text { Year } \\
\text { of } \\
\text { start } \\
\text { up } \\
\end{array}$ & duration & $\begin{array}{l}\text { Age of } \\
\text { respondent } \\
\text { at the start } \\
\text { of activity }\end{array}$ & $\begin{array}{l}\text { Number } \\
\text { of } \\
\text { activities }\end{array}$ & $\begin{array}{l}\text { Size of } \\
\text { employees }\end{array}$ \\
\hline Eric N. & 56 & $\mathrm{M}$ & Engineer & Employee & 1999 & 16 & 40 & 1 & 110 \\
\hline Adrien N. & 35 & M & Master 1 & $\begin{array}{l}\text { student/ assistant } \\
\text { in the family } \\
\text { firm }\end{array}$ & 2005 & 10 & 25 & 2 & 75 \\
\hline Stella & 46 & $\mathrm{~F}$ & $\begin{array}{l}\text { A level + } \\
2\end{array}$ & $\begin{array}{l}\text { Student/assistant } \\
\text { in the family } \\
\text { firm }\end{array}$ & 1993 & 22 & 24 & 1 & 4 \\
\hline Jean-Bosco & 63 & M & Bachelor & $\begin{array}{l}\text { Employee of } \\
\text { Bank }\end{array}$ & 1997 & 18 & 45 & 4 & 12 \\
\hline Cyprien & 47 & M & Master 1 & Student & 1992 & 23 & 24 & 5 & 13 \\
\hline Armand & 37 & M & A level & Student & 2009 & 6 & 31 & 3 & 9 \\
\hline
\end{tabular}

Source: authors own elaboration

The interviews were recorded in order to analyse the data in detail and focused on an interesting part of the interviews. The different interviews were carried out between September 2014 and March 2015.

The analysis was carried out at two levels. Firstly, an intra-case analysis of the development paths of the activities of each entrepreneur was made up based on the circumstances of the engagement in an entrepreneurship career, the evolution of the activities of the regulatory, fiscal and structural level. Secondly, the discussion used inter-case analysis in order to identify the converging behaviours of entrepreneurs with respect to literature.

\section{Results and Discussions}

\subsection{Summary of Cases and Presentation of the Profiles of the Development Path of Activities}

In order to study the transition strategy of enterprises, the speeches of entrepreneurs were recorded with respect to: the context of engagement in an entrepreneurial career, the initial situation of activities and the different evolutions of their activities. All these aspects were analyses with respect to three processes: the process of legalising, the taxation process and the accumulation or development process. The different cases are presented in the next sections.

\subsubsection{Case of Eric $\mathrm{N}$}

\section{- Context of Engagement in an Entrepreneurial Career}

Eric $\mathrm{N}$ is a civil engineer who studied in the United States. On his return, he passed a few years as a worker in his uncle's public works firm. However, his uncle's firm shuts down because of financial difficulties. This pushed the young engineer to work with several companies before creating his own enterprise in 2000, conscious of the fact that he says 'I could develop my ideas and contribute to the development of the nation'. He recognised that he got finance from a specialised organ of the government (FOGAPE) that give financial supports and accompanies enterprises. Eric $\mathrm{N}$ said, 'the contribution of entrepreneurs to the development of the country is large. As an employer, we reduce unemployment. We also pay taxes to the government'.

\section{- The Initial Situation of the Enterprise}

Legal: Eric $\mathrm{N}$ admitted that he has put in place all regulatory dispositions so as to conform at the launching of the activities of his enterprise. In fact, the customers targeted by his business asked him to have all legal documents. Thus, in order to conform to this exigency he indicates 'I had no choice'. He equally added that, it corresponds to the idea he had of an enterprise.

Fiscal: Eric N. Said he had accomplished all fiscal obligations despite the difficulties of his young enterprise. But with the experience of the shutdown of his uncle's enterprise, partly due to the fact that, State that was one of his customers, during the economic crisis did not pay its debts, the engineer said he had always taken his precautions so as to avoid bankruptcy. 'I have always declared fewer turnovers than the one I actually obtain. I mobilise a lot of liquidity and if I 
do not recover it, how will I meet up with the expenditures of my enterprise'.

About the number of activities, Eric N, told us that his enterprise evolves only in the public works sector. At the beginning, there were three permanent workers and when they had a contract, they recruited employees who had no contract with the enterprise.

\section{- The Path}

Despite the difficulties Eric N, operates legally and has been at the head of his enterprise for 15 years and wants his enterprise to remain legal.

Fiscal: Eric N. said with a payment system that obliges entrepreneurs to pre-finance the activities through loans from the bank where duration is between 60 to 90 days is too short compared to the dateline of payment of bills by State is 150 days and even more. In order to avoid bankruptcy, he was obliged to use corruption ties in order to speed up the treatment of his documents and manipulate figures so as to pay fewer taxes as possible.

Activity: Eric N. indicated that his enterprise has good established reputation with more than 100 permanent employees and an annual turnover of more than 1.3 billion CFA francs.

\subsubsection{Case of Adrien N}

\section{- Circumstances of Engagement in an Entrepreneurial Career}

Adrien N. is a holder of a Master in Marketing and international commerce obtained in France. When he went home for the holidays, he visited the production units of his parents and saw a lot of potential strength. Already interested in business, but hesitating due to the flawed and uncertain environment, he decided to sacrifice a year to study his environment and finally took the decision to go into business after the death of his father that same year. He took over the activities of his parents in wood and textile sector.

\section{- Initial Situation of the Enterprise}

Legal: the two activities evolve in the form of a Common initiative groups.

Fiscal: The firm has a status of cooperative and did not have the obligation to declare employees and pay taxes. This status as indicated by Adrien had the advantage of being hybrid. He highlights the fact that his father was an expert in accounting and he used this skill to falsify documents and gain from the advantages of a formal enterprise without actually paying all the fiscal expenditure related to its status.

Activity: the two activities had 15 permanent employees for an acceptable turnover, but small given their real potential.

\section{- The Path}

Legal: Adrien N. based on the recommendations of his legal adviser decided to change the common initiative group activities into separate SME. He decided to legalise the activities and optimise his relationship with financial institutions such as banks and international customers.

Fiscal: Adrien N. admitted that given the ambitions he has for these activities and the costs of his ambitions, he manipulates his accounts with the help of his expert accountant and declare less profit as possible with the aim of reducing tax expenditures. The real turnover is more than 200 million, but they declared only 90 million.

Activity: the two independent structures are flourishing and employ 75 persons. The ambition of Adrien N. is to gain in popularity, and become leader in the design of professional working uniforms in Central Africa, make his business grow, get a larger space, modernise management through the creation of a commercial and marketing department and the acquisition of accounting software. As for the wood activity, after the purchase of a saw machine he will henceforth supply finished products and not semi-finished products as he does presently with his foreign customers.

\subsubsection{Case of Stella}

\section{- Circumstances of Engagement in an Entrepreneurial Career}

Holder of a GCE A level in science, she spent two years at the University as an economics student, and made the choice of engaging in an entrepreneurial activity by conviction. In regards to the economic difficulties of the country towards the end of the 1990s, she did not see any future as a civil servant and unemployment was almost certain. After more than 10 years in the informal sector as market retailer with her grandmother, Stella decided to settle in the Douala central market where she specialised in the sales of baby products. She started with the sales of towels and baby diapers, and progressively increased the number of products.

\section{- Initial Situation of the Enterprise}

Legal: the exigencies of having a shop in the market, the bottlenecks of the fiscal administration with surprising controls and the pressure of corrupt controllers, Stella decided to get minimum administrative documents so as to limit 
the extortions of unscrupulous civil servants.

Fiscal: activity evolved in the informal tax regime.

Activity: Stella worked with her grandmother and gets the permanent assistance of two family members.

\section{- The Path}

Legal: the exigencies of formal suppliers with the evolution of the legislation was necessary in order to reduce the pressure from the controllers, she decided to seek the services of a fiscal (tax) adviser.

Fiscal: according to Stella in order to survive from the corruption of controllers, she did not have to declare all the income. For example, she said with retailing and purchases from small, informal artisans there are no invoices and it is carried out without any traces. Thus, an activity that have a real turnover of more than 300 million, but declared less than 90 million to the tax authorities. She justified this behaviour by the fact that during controls, the expenditures effectively paid to inspectors, according to the receipts presented were not up to $2 / 5$ of the amount. The rest is swindled by corrupt civil servants.

\subsubsection{Case of Jean Bosco}

\section{- Circumstances of Engagement in an Entrepreneurial Career}

Jean Bosco, is a holder of a bachelor's degree in economics. He is a former banker who got into business after he was fired for economic reasons due to the difficulties of the banking sector towards the 1990s. The indemnities he received enabled him to start his activity in 1996 in a small business in the textile sector.

\section{- Initial Situation of the Enterprise}

Legal: Jean Bosco, operated for 8 years in total informality. His activity was in his home and therefore could escape from all controls.

Fiscal: the clandestine nature of his activity guaranteed the absence of a relationship with the fiscal administration (tax authorities).

Activity: the initial activity was the design of diapers and bed sheets. He bought three sewing machines, recruited three seamstresses and started the activity. He supplied the products in large shops and super markets. It was difficult, but he struggled like that for 8 years. Everything was produced at home.

\section{- The Path}

Legal: Jean Bosco argued that with the hardening of the regulation his suppliers and customers (super markets and large shops) requested legal documents. Thus, in 2005 he created a small establishment. However, the movement of the sector towards disposal diapers made him to increase his line of products and open a shop in the city of Douala, a second shop in Yaounde city, and a third in Bafoussam city. Finally he also breeds pigs.

Fiscal: For 6 years $(2005$ - 2010), these activities evolved under the informal tax regime for the shop of the Douala central market. In 2011, it moved to the business licence regime and in 2013 moved to the real regime all these under the pressure of tax officers. However, to avoid to be classified under the regime of SME since the turnover is evolving very well Jean Bosco decided to open a shop in another town that enables him to reduce the turnover of a shop. In Yaounde and Bafoussa, the shops also evolve in the business licence regime, but in the simplified category. In addition the piggery is in the village thus it is not declared: he supplied in three markets in Bafoussam city, He sells six pigs averagely every day, two in each market. He equally had an employee who cooks and sells meat in the off licence of his second wife in Bafoussam. Finally, Jean Bosco admitted that he had fewer problems with the tax collector since he had all documents. However, he is obliged to manipulate the charges in order to pay lower taxes. Moreover, some clandestine activities are invisible to tax collectors. Thus, the piggery does not pay any taxes and since it is in the village the salaries of youths, who worked there, did not cost much.

\subsubsection{Case of Cyprien F}

\section{- Circumstances of Engagement in the Entrepreneurial Career}

Cyprien F. made his first steps in business beside his late father whom he holds his entrepreneurial passion. He took over the family business after the death of his father who initially had a firm in public works that went bankrupt in 1986, because the government did not pay its bills due to the economic crisis, after constructing two administrative buildings. After this unfortunate event, his father opened a bakery in Douala in 1990 but it was burnt down during the political crisis of 1992. When his father died in 1996, the young Cyprien F. decided to continue in the footsteps of his late father.

\section{- Initial Situation of the Enterprise}

Legal: the business that Cyprien F. took over had difficulties. The production unit that was burnt down had to be re-launched. However, activity was completely legalised. 
Fiscal: Cyprien F. assisted his father confirms that the enterprise was registered under the real regime, but operated by declaring the least turnover as possible.

Activity: according to the commerce register, the activity of the enterprise was a bakery and had eight permanent workers.

\section{- $\quad$ The Path}

Legal: Given the impossibility of obtaining financing and recovering the production unit, Cyprien F. who become the family head indicates that for more than 25 years the government has not settled his father. He introduced a court case, but there was no progress and he abandoned. He opened the artisanal bakery, done in the context of a political crisis to survive after the formal bakery was burnt down. However, he said later on the difficulties of re-launching and the fear of being exposed one more to such an act, he completely forgot the advantages that a formal activity can have and he decided to operate informally. The choice of operating informally and the activities he carried out are defensive and preventive reactions to the unscrupulous behaviour of State agents. Cyprien F. equally admitted that since the common behaviour in the country is manipulation, he decided to make an arrangement with controllers rather than legalising his documents. In addition, in our country, nothing is done to those who remain in the informal sector, why should he legalise his business when others are living at peace in informality with the blessing of the administration, he said.

Fiscal: .Cyprien F. supports that his bakery remained informal to pay homage to his father, and try to seek justice for him. Equally, given what happened to his father he supported the fact that one should not put everything in one endeavour. However, he added that for all the other activities, he chose it according to the possibility of gaining big profits and pay lower taxes as possible. In a sense the shops are under the informal tax regime, the bakery and the restaurant are completely unknown or at least he negotiates with control agents.

Activity: Twenty years after Cyprien F. operates the same activities, but has equally acquired taxis, motorcycles, has opened three shops in the neighbourhoods of the town and has a restaurant managed by his wife since 2000 .

\subsubsection{Case of Armand T}

\section{- Circumstances of Engagement in the Entrepreneurial Career}

After obtaining his GCE A level Armand T. just like any young looked for a salaried work and wrote several competitive entrance examinations but he failed. He went to the National Employment Fund (NEF) and received training in secretariat studies. However, he failed to insert himself into the labour market. Once again, he knocked at the door of the National Employment Fund that sent him to a barber for training and at the end of the training; he received funding to open a barbing saloon. In fact, the young man confirms that he started from the idea that in the town of Yaounde, there was no place, where men could shave themselves very well and most beauty institutes were meant for women.

With the funds obtained and support from different parents, he decided to open a modern barbing saloon in Yaounde. His sister who lives in Europe had a villa in the residential neighbourhood of Yaounde; he decided to arrange part of the villa for the barbing saloon. The selective customer paid very well, he said.

\section{- Initial Situation of the Enterprise}

Legal: the barbing saloon operated totally in the informal sector.

Fiscal: the activity did not really had contacts with tax collectors since it is in a private villa.

\section{- $\quad$ The Path}

Legal: despite the prosperity of the business, he did not intend to become formal since his solid protection guarantee coverage against the controllers. With the new law on voluntary insurance, he has matriculated eight employees at the National Social Insurance Fund so as to make the difference with other small barbers and retain his employees.

Fiscal: Even though the barbing saloon is visible and accessible to tax collectors, it is operating with the informal tax regime as the proprietor confirms. He had an annual turnover of about 16 million for the barbing saloon and up keep, activities and massage generated practically 10 million.

Activity: taken to the residence of a minister by his son who he has been shaving regularly for more than one year, he was advised to diversify his business. He decided to visit his sister in Europe with the idea of learning modern massage techniques. On his return, he started proposing this service to a selected client at home and in the institute. Moreover, he decided to diversify his customer that was no longer entirely masculine. Today, he admitted that business is flourishing the masculine and feminine customers are mostly high class of the Cameroonian society. In 2014, he added a third activity to his business. 
4.2 Dynamic of the Evolution of the Degree of Formalization of Business Activities: Description of the Choice of Dissimulated Facades and Proof of the Strategic Capacity of Entrepreneurs in the Informal Sector

\subsubsection{The Path of Perfect Side of Legal Formalization: Choice of the Opportunistic Degree of Legalization}

Concerning perfect side of legal formalization, the results of the survey revealed that entrepreneurs opt for several paths. This revelation confirms the results of other studies on the existence of continuum degrees of legal conformity (Williams \& Shahib, 2016). The paths here are of three types: positive evolution where informal enterprises mutate to completely or partially formal enterprises, the negative evolution where enterprises move from very formal to partially formal or to very informal, and the status quo where enterprises maintain its activities in initial status.

These choices show how entrepreneurs of the informal sector are very concerned with the future of their enterprise and consequently use their strategic capacity of reflection. First, entrepreneurs follow the evolution of their environment and are capable of perceiving opportunities, take advantage and develop it. In fact, an opportunistic logic aimed at benefiting from the advantages of the status chosen. So legalised enterprises want to enjoy the advantages of legality and non-legalised enterprises or informal activities want to escape from constraints linked to different declarations and to the payment of taxes and duties. Secondly, the fact that the activities are able to survive despite the pressure of control is possible only because the entrepreneurs have other strategic abilities such as the establishment of win-win coalitions with the actors in charge of control.

These results are opposed to the view of Bocco (2013) regarding the place that managers of small firms give to their future. The results are also in line with Patton, Marlow, and Hannon (2000) who supports the fact that small units have entrepreneurial orientations for the future that enable them to achieve a certain level of performance. In fact, if the capacity of strategic reflection of formal entrepreneurs was recognised by Patton and his colleagues, in our knowledge, no study has shown this capacity for entrepreneurs of the informal sector (mostly presented in the literature as persons of low intellectual capacity and who move into this sector because of the necessities or the need to survive) but this current study stress that informal entrepreneurs have the capacity of strategic reflection. Furthermore, if the high level of unemployment has left several graduates from the university without jobs and pushed them to engage in the informal sector, then it is not surprising that their intellectual capacities can help them to develop opportunities, strategies for the development of their business and used degrees of legalization that can enable them to achieve a good level of performance.

The level of education appears to have a positive impact on the success of the enterprise and increases the tendency of entrepreneurs to operate formally (Copisarow, 2004 and Copisarow \& Barbour, 2004). In the same line with these authors, this study revealed that all respondents have a higher level of education that can enable them to formalize their activities. So, the choice of not formalizing can be therefore related to the fact that despite their capacity of strategic analysis, entrepreneurs do not find a higher comparative advantage from formal activity (sector) compared to the informal sector.

4.2.2 The Path of Conformity to the Obligations of Legalization and the Structural Development of Activities. Dissimulated Side: A Fraud Management Behaviour

The second process is aimed to present the modalities of deviating from obligations and other constraints of legality. The results of the survey revealed that major entrepreneurs choose to stand at mid-way of what is expected from them. For each of the constraints examined, it appears on one hand the will to stage legality for those who opted for the evolution; and on the other hand, there is equally an effort not to respect the constraints of legality. For those who were not registered, whereas they had all the means to do it, the turnover was above the regulatory minimum required. Therefore, legality is a choice of facade and fraud management is a strategy to respond to the pressures of legality. Enterprises that are legalised move from gray administrative area to the gray fiscal area. Entrepreneurs who maintain their activities in legality equally remain in the fiscal gray area. The enterprises that have opted for informality paths are in the administrative gray area. The results confirm the exceptional characteristic of the status of total formality and total informality (Williams \& Shahib, 2014).

The manipulation of accounting information and negotiation with agents of control are the major modalities of avoidance the obligations of legality. These tactics enable entrepreneurs to stage, according to the terminology of Goffman (1973) dissonant facade choices with the decorated side (legalization) and the dissimulated side, the non-respect of legal obligations. Thus, entrepreneurs that have chosen to legalise their activities do not remain less informal since their practices are partially informal. In fact, they pay taxes but not honestly, do accounting but not honestly, the personnel are registered but not entirely. This is the logic of appearance that is the logic of staging the formal while in fact remaining informal.

With respect to the study of Ngantchou (2013), the results indicated a dishonest fiscal behaviour of enterprises in Cameroon and it equally affects large SME as well as small ones and even informal or partially informal enterprises. All these enterprises cheat, manipulate or distort accounting information. However, the results are in line with Ngantchou 
(2013) who argued that manipulating accounting information is not a weakness due to the quality of the dispositions of the accounting framework put in place, but probably due to the preparatory behaviour of accounting information. The results indicate that this tendency is reinforced by the institutional system.

Darbon (2001) argued that in Africa, most civil servants close to illiteracy are characterised by weak technical competence and weak capacity of the interpretation of acts and procedures. These civil servants are often poorly or not trained enough, do not have enough material means, not well paid or not paid at all and poorly supervised by the top hierarchy often busy with politics instead of defending a good bureaucratic management balance sheet. The top civil servants with high competence trained in universities especially abroad see the civil service as an obligatory path towards access to political opportunity, elective or international.

The results of this study revealed that control agents in Cameroon have a similar behaviour such as the one described by Darbon (2001) above. Corruption of civil servant leads to multiple arrangements, and it is at the origin of the first forms of daily corruption. Moreover, it reveals incompetence, dishonesty, the impunity of the personnel, and the wastage of material (Desardan, 2004). The results also confirm the existence of different practices revealed by Desardan (1996) calls 'complex corruption'. He explained 'complex corruption' through six logical action links to cultural entrenchment (deeply rooted in the current social life and that are usually behavioural norms) of corruption in Africa. It includes: the logic of negotiation, the logic of courtesy, the logic of gifts, the logic of the duty of inter-assistance in networks, the logic of predatory authority and the logic of redistributive accumulation. All these logics seem to be validated in the above results mainly in relationships between entrepreneurs and civil servants. In this study, corruption is used by entrepreneurs as a tactic to reduce legal constraints of enterprises either by negotiating their maintenance in the informal sector or for negotiating the non-payment or partial payment of taxes and duties for formal enterprises.

The other logic of deviation of the obligations of legality was revealed mainly by the entrepreneurs who have chosen the path of informality emanate from the strategy of development of activities. In fact, entrepreneurs revealed that to avoid being classified in higher tax levels, they prefer the diversification of risk by poly-activity instead of linear growth. This logic is the logic of tax fraud and tax evasion. Equally, if the enterprises that are made up of formal activities do not add new activities, they usually opted for linear growth. The main reason of the choice of diversification given by entrepreneurs is the minimisation of risks of being classified at a higher tax level. The results are in line with Hugon (2014) who indicates that the dominant development strategy of informal enterprises is differentiation of risk by poly-activity. In fact, these entrepreneurs are trying to accumulate profits (wealth) and priority is given to the sustainability and independence of businesses. Growth is reactive and is accepted only when it does not oppose to the sustainability and independence of the enterprise.

\subsubsection{The Choice of Partial Conformity: The Logic of Gray Area}

In Cameroon context, the formalization of business activities is done with respect to the logic of profit, opportunism and strategies. In fact the choice of legality is accompanied by legal constraints. However the motivations towards formalization are instrumental (Bakehe, 2016 and Cantaens, 2012). Odegaard (2008) argued that the gray area presented activities that are between informal and formal, in order words, these activities have a hybrid status. Abate (2017), argued that entrepreneurs choose gray area in order to take advantages of both status (formal and informal at the same time). The results of this study revealed that entrepreneurs choose legality to take advantages offer by legality, and they developed survive strategies to avoid constraints related to legal functioning. In fact, entrepreneurs are opportunist actors that pursue the performance of their business activities. So they studies their environment and take the maximum advantages from the weaknesses of this environment. However, when they cannot avoid legal constraints they conform to it (Abate, 2017). At the creation entrepreneurs can fulfilled formal requirement. However, when it comes to pay tax, they choose informal practices (with the help of corrupted control agent). Therefore the logic of gray area, is the combination of the strategic choice of entrepreneurs and the weaknesses of environment mainly the behaviour of civil servant. The entrepreneurs choose to be conformed to the exigencies of operational partners and negotiated with the corrupted institutional environment.

\section{Conclusion}

The objective of this study was to highlight the strategies of formalization and the development of activities base on the analysis of the path of the formalization of the activities of six entrepreneurs in Cameroon. The results revealed that despite the accumulation capacity of entrepreneurs some of their activities evolve in the informal sector by convenience, opportunism and opportunity. This study dissociates itself from the idea that entrepreneurs of small businesses have no strategic capacity. On the contrary the results show that entrepreneurs of the informal sector have strategic capacities that enable them within the framework of reflections on the development of their activities, to stage degrees of formalization that guarantee good performance and less constraints. Therefore, the informal sector does not appear as a nursery for formal enterprises.

In fact, when entrepreneurs think about developing their activities, they prefer to develop: some activities that appear 
informal (pure side) even when the level of accumulation is more than the limit required by the administration (dissimulated side) and other activities that appear formal (pure side so as to benefit from the opportunities offered in this category of business) and do not conform to the constraints of legality (dissimulated side). This fact can be related to the logic of dissonant facade with the validation of the strategy of fraud management where tactics used varying including: manipulation of accounting information, corruption by negotiation and the formation of coalitions with civil servants in charge of control or the choice of multiplication of activities or extensive accumulation. Some entrepreneurs also choose partial conformity (logic of gray area).

The contributions of this study are: theoretical, managerial and methodological. At the theoretical level, a research that used Goffman (1973) metaphor of representation of oneself puts into evidence the opportunistic behaviours of entrepreneurs regarding the choice of the degree of formalization of activities. At the managerial level, the carriers of entrepreneurs presented in this study highlight the practices of entrepreneurs and their strategies to survive and develop their businesses. At the methodological level, the method of live recitation that gives opportunity for actors to talk about their career, respond to the question of how entrepreneurs choose the development paths of their activities.

However, like any research this study has limitations that are equally perspectives of improvement and venues of further research. Thus, the sample is made up of the higher range of the informal economy. Just as a pyramid (with a large base); this sector is mainly made up of survival activities without accumulation capacity. However, the sample used in this study could therefore be extended to all the categories in the informal sector.

\section{Acknowledgements}

The authors want to thank Prof. Josee St-Pierre for his comments and suggestions on the first draft of this paper and the two anonymous reviewers for their comments and suggestions.

\section{References}

Abate, A. M. (2017). Transition des entreprises informelles vers le formel: Les zones grises comme stratégie entrepreneuriale de façade (Transition of informal enterprises to formal: the gray areas as strategie of entrepreneurial facade), Revue Africaine de Management, 2(1), 1-21.

Albrecht, W. S. (2003). Fraud Examination, Thomson South-Western Publishing.

Bakehe, N. P. ( 2016). Informalité et poductivité des tres petites et petites entreprises au Cameroun (Informality and productivity of very small and small enterprises in Cameroon), Innovations, 3(51), 105-124. https://doi.org/10.3917/inno.051.0105

Berrou, J. P. (2014). Entrepreneurs du secteur informel (Entrepreneurs of informal sector), in Pierre-Marie Chauvin et al. Dictionnaire sociologique de l'entrepreneuriat, Presses de Sciences Po (P.F.N.S.P.), $227-243$.

Bocco, B. S. (2013). Gestion de la Vulnérabilité des Petites Entreprises dans un environnement turbulent : entre un comportement planifié et opportuniste (managing small enterprises in changing environment). Humanisme et Entreprise, (1), 1-20.

Cantaens, T. (2012). Les pratiques commerciales informelles (informal commercial practrices). Document de recherche de l'OMD, 22, 16.

Cheriet, F. (2013). Pratiques managériales frauduleuses en Algérie : Diversité, ampleur et perceptions des acteurs, (Fraud in management practrices in Algeria : Diversity and perception of actors). Institut national de la recherche agronomique No. hal-01485482

Copisarow, R. (2004). Street UK - A Micro-finance Organisation: Lessons Learned from Its First Three Years' Operations, Street UK, Birmingham. United Kingdom.

Copisarow, R., \& Barbour, A. (2004). Self-Employed People in the Informal Economy-Cheats or Contributors: Evidence, Implications and Policy Recommendations, Community Links, London.

Darbon, D. (2001). De l'introuvable à l'innommable : fonctionnaires et professionnels de l'action Publique, (The wanted to no name: civil servants and professional of public action) dans les Afriques, Autrepart, 4(20), 27-42. https://doi.org/10.3917/autr.020.0027

DeSardan, J. P. O. (1996). Economie morale de la corruption en Afrique, (Moral economy and corruption in Africa) Politique Africaine, 63, 97-116. ISSN 0244-7827.

Desardan, J. P. O. (2004). État, bureaucratie et gouvernance en Afrique de l'Ouest francophone :Un diagnostic empirique, une perspective historique (State, bureaucratie and governance in francophone West Africa: An empirical dignostic and historical perspective), Politique africaine, 4(96), 139-162.

Diagne, Y. S., \& Thiaw, K. (2008). Fiscalité et secteur informel au Sénégal (Taxation and informal sector in Senegal). Ministère de l'Economie et des Finances, DPEE/DEPE, Document d'étude $\mathrm{N}^{\circ} 09$. 
Eisenhardt, K. M. (1989). Agency theory: An assessment and review. Academy of management review, 14(1), 57-74. https://doi.org/10.5465/AMR.1989.4279003

Goffman, E. (1973). La mise en scène de la vie quotidienne (The staging of everyday of life). Tome 1. La présentation de soi. Paris, Minuit.

Hugon, P. (2014). L'informel ou la petite production marchande revisités quarante ans après (informal or small market production review fourty years later). Mondes en développement, 2(166), 17-30. https://doi.org/10.3917/med.166.0017

La porta, R., \& Shleifer, A. (2014). Informality and development. The Journal of Economic Perspectives, 28(3), 109-126. https://doi.org/10.1257/jep.28.3.109

Labazee, P. (2000). Petits patrons africains: entre l'assistance et le marché (Small African boss: between assistance and market), Paris, Karthala Editions.

Mead, D., \& Morisson, C. (1996). The informal sector elephant. World Development, 24(10), 1611-1619. https://doi.org/10.1016/0305-750X(96)00065-4

Menguelti, S., Perret. C., \& Abrika, B. (2014). A la croisée du formel et de l'informel : les entreprises créés par le dispositif de l'Agence Nationale de Soutien à l'Emploi des Jeunes dans la Wilaya de Tizi-Ouzou ( Between formal and informal : the enterprises created by National Agency for sustain to Youth in Wilaya de Tizi-Ouzou) Notes de Recherches, IREGE, Université de Savoie.

Mouko, J. P. (2015). Les dynamiques de l'économie informelle en Afrique subsaharienne : une étude empirique de la transition structurelle des micro-entreprises en République du Congo, (The dynamism of informal economy in sub sahara Africa : an empirical study in structural transition of micro enterprises in Republic of Congo) (Doctoral dissertation, Versailles-St Quentin en Yvelines).

Ngantchou, A. (2013). L'influence du profil éthique du propriétaire-dirigeant sur le contenu informatif des nombres comptables (The influence of ethical profile of proprietor- manager on the content of accounting numbers). Revue internationale P.M.E.: économie et gestion de la petite et moyenne entreprise, 26(2), 13-36. https://doi.org/10.7202/1024319ar

Odegaard, C. (2008). Informal trade, Contrabando and Prosperous Socialities in Arequipa, Peru, Ethos, 73(2), 241-266.

Patton, D., Marlow, S., \& Hannon, P. (2000). The relationship between training and small firm performance, research frameworks and lost quests. International Small Business Journal, 19(1), 11-27. https://doi.org/10.1177/0266242600191001

Rispal, M. H., \& Jouison, L. E. (2015). La contribution des méthodes qualitatives au développement du champ de l'entrepreneuriat (The contribution of qualitative methods to the development of the field of entrepreneurship). Revue de l'Entrepreneuriat, 14(1), 15-40. https://doi.org/10.3917/entre.141.0015

Van Peursem, K., Zhou, M., Flood, T., \& Bultimore, J. (2007). Three cases of corporate fraud: an audit perspective, working paper, $\mathrm{N}^{\circ} 94$, Waikato University, June. 45 pages.

Wells, J. (1997). Corporate fraud handbook: Prevention and Detection. Hoboken, New Jersey: Wiley.

Williams, C. C., \& Martinez, A. (2014). Do small business start-ups test-trade in the informal economy? Evidence from a UK survey. International Journal of Entrepreneurship and Small Business, 22(1), 1-16. https://doi.org/10.1504/IJESB.2014.062127

Williams, C. C., \& Shahid, M. S. (2016). Informal entrepreneurship and institutional theory: Explaining the varying degrees of (in) formalization of entrepreneurs in Pakistan. Entrepreneurship and Regional Development, 28(1-2), 1-25. https://doi.org/10.1080/08985626.2014.963889

Yin, R. K. (1994). Case study research: Design and methods, (2nd ed.). Newbury Park, CA: Sage Publications.

Yin, R. K. (2003). Case study research: design and methods, applied social research methodsseries. Thousand Oaks, CA: Sage Publications, Inc. Afacan, Y., \& Erbug, C. (2009). An interdisciplinary heuristic evaluation method for universal building design. Journal of Applied Ergonomics, 40, 731-744. https://doi.org/10.1016/j.apergo.2008.07.002

\section{Copyrights}

Copyright for this article is retained by the author(s), with first publication rights granted to the journal.

This is an open-access article distributed under the terms and conditions of the Creative Commons Attribution license which permits unrestricted use, distribution, and reproduction in any medium, provided the original work is properly cited. 